\title{
AN EMPIRICAL ANALYSIS OF ALCOHOL \\ ADDICTION: RESULTS FROM THE MONITORING THE FUTURE PANELS
}

\author{
Michael Grossman \\ Frank J. Chaloupka \\ Ismail Sirtalan
}

Working Paper No. 5200

\section{NATIONAL BUREAU OF ECONOMIC RESEARCH 1050 Massachusetts Avenue \\ Cambridge, MA 02138 \\ July 1995}

This paper is part of NBER's research program in Health Economics. Any opinions expressed are those of the authors and not those of the National Bureau of Economic Research.

(C) 1995 by Michael Grossman, Frank J. Chaloupka and Ismail Sirtalan. All rights reserved. Short sections of text, not to exceed two paragraphs, may be quoted without explicit permission provided that full credit, including (C) notice, is given to the source. 


\title{
AN EMPIRICAL ANALYSIS OF ALCOHOL \\ ADDICTION: RESULTS FROM THE \\ MONITORING THE FUTURE PANELS
}

\begin{abstract}
This paper aims to refine and enrich the empirical literature dealing with the sensitivity of alcohol consumption and excessive consumption to differences in the prices of alcoholic beverages. The main refinement pertains to the incorporation of insights provided by a model of rational addictive behavior which emphasizes the interdependency of past, current, and future consumption of an addictive good. The data employed in this study consist of a U.S. panel whose members range in age from seventeen through twenty-seven. Since the prevalence of alcohol dependence and abuse is highest in this age range, addictive models of alcohol consumption may be more relevant to this sample than to a representative sample of the population of all ages. We find that alcohol consumption by young adults is addictive in the sense that increases in past or future consumption cause current consumption to rise. The positive and significant future consumption effect is consistent with the hypothesis of rational addiction and inconsistent with the hypothesis of myopic addiction. The long-run elasticity of consumption with respect to the price of beer is approximately 60 percent larger than the shortrun price elasticity and twice as large as the elasticity that ignores addiction.
\end{abstract}

Michael Grossman

Ph.D Program in Economics

City University of New York Graduate School

33 West 42 nd Street

New York, NY 10036

and NBER

Ismail Sirtalan

Greater New York Hospital Association

555 West 57th Street

New York, NY 10019
Frank J. Chaloupka

Department of Economics

University of Illinois, Chicago

601 South Morgan Street

Chicago, IL 60680

and NBER 
Becker and Murphy (1988) develop a theoretical model of addictive behavior which assumes that individuals behave rationally. The main element of this and other models of addictive behavior is that an increase in past consumption of an addictive good raises the marginal utility of current consumption and therefore raises current consumption. A key feature of the Becker-Murphy model which distinguishes it from other models of addictive behavior is that addicts are rational or farsighted in the sense that they anticipate the expected future consequences of their current actions. This is in sharp contrast to myopic models of addiction in which consumers ignore the effects of current consumption on future utility when they determine the optimal or utility-maximizing quantity of an addictive good in the present period.

Several interesting, empirically testable predictions are generated by the Becker and Murphy analysis. These include a bimodal distribution of consumption, intertemporal complementarity of consumption or negative cross price effects, a long-run own price elasticity of demand which exceeds the short-run elasticity (the former allows past consumption to vary while the latter does not), and "cold turkey" quit behavior. Intertemporal complementarity--a key aspect of rational addiction models--arises because increases in past or future consumption (caused by reductions in past or future prices) cause current consumption to rise. Put differently, the reinforcement property of an addictive good, which is emphasized by psychologists, suggests that an increase in past consumption raises the marginal benefit of current consumption. By symmetry, an increase in future consumption also raises the marginal benefit of current consumption.

This model has been successfully applied to the addictive behavior of cigarette smoking in published research by Becker, Grossman, and Murphy 
(1994); Chaloupka (1991); and Keeler, Hu, Barnett, and Manning (1993).1 Becker, Grossman, and Murphy (1994) estimate demand functions using a time series of state cross sections covering the 50 states of the U.S. and the District of Columbia from 1955 through 1985. They find substantial support for the hypotheses that cigarette smoking is an addictive behavior (in the sense that an increase in past consumption of cigarettes raises current cigarette consumption) and that individuals are farsighted (in the sense that an increase in future consumption of cigarettes raises current consumption). The sizable long-run price elasticity of demand of approximately -0.75 is almost twice as large as the short-run price elasticity of -0.40 . Smoking levels in different years appear to be complements: cigarette consumption in any year is lower when both future prices and past prices are higher.

Chaloupka (1991) and Keeler, Hu, Barnett, and Manning (1993) provide further evidence in support of the rational model of cigarette addiction. Chaloupka's study is based on a micro data set: the Second National Health and Nutrition Examination Survey, conducted from 1976 through 1980. He finds a short-run price elasticity $(-0.20)$ that is less than one-half of the long-run price elasticity of -0.45 . The positive and statistically significant future consumption coefficient in his estimated demand function is further evidence against myopic addiction. Similar results emerge from the study by Keeler, Hu, Manning, and Barnett which is based on monthly data on per capita consumption of cigarettes in California for the years from 1980 through 1990 and capitalizes on the dramatic increase in the tax on cigarettes in that state from 10 cents to 35 cents per pack on January 1, 1989. They find that an increase in past or future consumption raises current consumption, a shortrun price elasticity of -0.36 , and a long-run price elasticity of -0.58 . 
Substantial econometric effort has been devoted to estimating the demand for alcohol (see Grossman 1993 and Leung and Phelps 1993 for detailed reviews of this literature). In addition to establishing inverse relationships between price and alcohol consumption, this literature shows that the death rate from cirrhosis of the liver (a standard measure of excessive consumption) and the fraction of persons who drink frequently or heavily fall as the price of alcohol rises. The theoretical and empirical frameworks employed in these studies, however, have generally ignored the addictive aspects of alcohol. This may be because attempts to apply models of addictive behavior to alcohol demand are inherently more difficult than applications to cigarette demand because the former is not nearly as addictive as the latter. Many persons consume small quantities of alcohol but not cigarettes. Put differently, the distribution of alcohol consumption is more continuous than the bimodal distribution that Becker and Murphy (1988) demonstrate is more likely to characterize the consumption of addictive goods.

This paper aims to refine and enrich the empirical literature dealing with the sensitivity of alcohol consumption and excessive consumption to differences in the prices of alcoholic beverages. The main refinement pertains to the incorporation of insights provided by the Becker-Murphy model of rational addictive behavior which emphasizes the interdependency of past, current, and future consumption of an addictive good. The data employed in this study consist of the panel formed from the nationally representative cross-sectional surveys of high school seniors conducted each year since 1975 by the Institute for Social Research of the University of Michigan. The members of the panel range in age from seventeen through twenty-seven. Since the prevalence of alcohol dependence and abuse is highest in this age range 
(Grant et al. 1991), addictive models of alcohol consumption may be more relevant to this sample than to a representative sample of the population of al1 ages.

We find that alcohol consumption by young adults is addictive in the sense that increases in past or future consumption cause current consumption to rise. The positive and significant future consumption effect is consistent with the hypothesis of rational addiction and inconsistent with the hypothesis of myopic addiction. The long-run elasticity of consumption with respect to the price of beer (the alcoholic beverage of choice by young adults) is approximately 60 percent larger than the short-run price elasticity and twice as large as the elasticity that ignores addiction.

These results bear on evaluations of policies to increase the federal excise tax on beer to help finance national-health care reform, reduce the federal deficit, or curtail youth alcohol abuse. Forecasts of increases in tax revenue from this age group due to hikes in the federal excise tax on beer would be considerably overstated and forecasts of reductions in consumption would be considerably understated if they were not based on the long-run elasticity. Thus, a tax hike to curtail abuse would have a more favorable cost-benefit ratio than one to raise revenue.

\section{Analytical Framework}

Following Becker, Grossman, and Murphy (1994), we assume that consumers maximize a lifetime utility function given by

$$
V=\sum_{t=1}^{\infty} \beta^{t-1} U\left(Y_{t}, C_{t}, C_{t-1}, e_{t}\right)
$$

Here $Y_{t}$ is consumption of a non-addictive good at time or age $t, C_{t}$ is 
consumption of an addictive good (alcohol in our case) at age $t, C_{t-1}$ is alcohol consumption at age $t-1, e_{t}$ reflects the effects of unmeasured life cycle variables on utility, and $\beta$ is the time discount factor $[\beta=1 /(1+r)$, where $r$ is the rate of time preference for the present]. ${ }^{2}$ An increase in lagged alcohol consumption $\left(C_{t-1}\right)$ lowers utility if the addiction is harmful $\left(\partial U / \partial C_{t-1}<0\right)$, while an increase in the lagged consumption raises utility if the addiction is beneficial $\left(\partial \mathrm{U} / \partial \mathrm{C}_{\mathrm{t}-1}>0\right)$. Presumably, the partial derivative just defined is negative, although the model simply assumes that this term is nonzero. ${ }^{3}$ Regardless of the nature of the addiction, an increase in past consumption must raise the marginal utility of $C_{t}$ in order for an increase in past consumption of $C$ to increase current consumption. When the utility function is quadratic and the rate of time preference for the present is equal to the market rate of interest, equation (1) generates a structural demand function for consumption of $C$ of the form $C_{t}=\theta C_{t-1}+\beta \theta C_{t+1}+\theta_{1} P_{t}+\theta_{2} e_{t}+\theta_{3} e_{t+1}$

Here $P_{t}$ is the price of $C_{t}$, and the intercept is suppressed. Since $\theta$ is positive and $\theta_{1}$ is negative, current consumption is positively related to past and future consumption $\left(C_{t-1}\right.$ and $C_{t+1}$, respectively) and negatively related to current price. In particular, $\theta$ measures the effect of an increase in past consumption on the marginal utility of current consumption. By symmetry, it also measures the effect of an increase in future consumption on the marginal impact of current consumption on next period's utility. The larger the value of $\theta$ the greater is the degree of reinforcement or addiction.

Equation (2) is the basis of the empirical analysis in this paper. Note that ordinary least squares estimation of the equation might lead to biased estimates of the parameters of interest. The unobserved variables that affect 
utility in each period are likely to be serially correlated. Even if these variables are uncorrelated, $C_{t-1}$ and $C_{t+1}$ depend on $e_{t}$ and $e_{t+1}$ through the optimizing behavior. These relationships imply that an ordinary least squares estimation of the equation might incorrectly imply that past and future consumption affect current consumption, even when the true value of $\theta$ is zero. Fortunately, the specification in equation (2) suggests a way to solve the endogeneity problem. The equation implies that current consumption is independent of past and future prices when past and future consumption are held constant; any effect of past or future prices on current consumption must come through their effects on past or future consumption. Provided that the unobservables are uncorrelated with prices in these periods, past and future prices are logical instruments for past and future consumption, since past prices directly affect past consumption, and future prices directly affect future consumption. Therefore, the empirical strategy amounts to estimating equation (2) by two-stage least squares, with past and future prices serving as instrumental variables for past and future consumption.

This strategy can be modified when measures of some of the life cycle events that affect utility and therefore partially determine $e_{i}$, such as marital status and unemployment, are available. If $\partial^{2} U / \partial e_{t+1} \partial C_{z}$ equals zero, while $\partial^{2} U / \partial e_{t} \partial C_{t}$ is nonzero, $C_{t}$ depends on $e_{t}$ but not on $e_{\imath+1}$ in equation (2). Then current marital status, for example, is a relevant regressor in the structural demand function given by equation (2), and past and future marital status are instruments for past and future consumption.

The statistical significance of the coefficient of future consumption provides a direct test of a rational model of addiction against an alternative model in which consumers are myopic. In the latter model they fail to 
consider the impact of current consumption on future utility and future consumption. That is, the myopic version of equation (2) is entirely backward looking. In it current consumption depends only on current price, lagged consumption, the marginal utility of wealth (which is one of the determinants of the current price coefficient), and current events. Because of these distinctions, myopic models and rational models have different implications about responses to future changes. In particular, rational addicts increase their current consumption when future prices are expected to fall, but myopic addicts do not.

Equation (2) implies intertemporal complementarity or negative cross price elasticities between alcohol consumption at various points in time. These effects pertain to changes in the price of alcohol in period $\tau$ on consumption in period $t$. They are temporary in nature since prices in other periods are held constant. For example, a reduction in price in period t-l $\left(P_{t-1}\right)$ with prices in all other periods held constant will increase consumption in that period. In turn, $C_{t}$ will rise since $\theta$ is positive. Along the same lines, a reduction in $P_{t+1}$ with prices in all other periods held constant will increase $C_{t+1}$, which will increase $C_{t}$ since $\beta \theta$ is positive.

Equation (2) also implies that there are important differences between long- and short-run responses to permanent price changes (price changes in more than one period) in the case of addiction. The short-run price effect describes the response to a change in price in period $t$ and all future periods that is not anticipated until period $t$. The long-run price effects pertains to a price change in all periods. Since $C_{t-1}$ remains the same if a price change is not anticipated until period $t$, the long-run price effect must exceed the short-run price effect. 
These results can be seen more formally by solving the second-order difference equation in (2). The solution, which is contained in Becker, Grossman, and Murphy (1994), results in an equation in which consumption in period $t$ depends on prices and life-cycle variables in all periods. The roots of this difference equation are

$$
\phi_{1}=\left[1-\left(1-4 \theta^{2} \beta\right)^{1 / 2}\right] / 2 \theta, \phi_{2}=\left[1+\left(1-4 \theta^{2} \beta\right)^{1 / 2}\right] / 2 \theta,
$$

with $4 \theta^{2} \beta<1, \phi_{1}<1$, and $\phi_{2}>1$ all for stability. Given these roots, the temporary current, past, and future price effects are

$$
\begin{aligned}
& \partial \mathrm{C}_{\mathrm{t}} / \partial \mathrm{P}_{\mathrm{t}}=\theta_{1} / \theta \phi_{2} \\
& \partial \mathrm{C}_{\mathrm{t}} / \partial \mathrm{P}_{\mathrm{t}-1}=\theta_{1} / \theta\left(\phi_{2}\right)^{2} \\
& \partial \mathrm{C}_{\mathrm{t}} / \partial \mathrm{P}_{\mathrm{t}+1}=\theta_{1} \phi_{1} / \theta \phi_{2} .
\end{aligned}
$$

All are negative since $\theta_{1}$ is negative. The short-run price effect is

$$
\partial C_{t} / \partial P=\theta_{1} /\left[\theta\left(1-\phi_{1}\right) \phi_{2}\right]
$$

while the long-run price effect is

$$
\mathrm{dC} / \mathrm{dP}=\theta_{1} /\left[\theta\left(1-\phi_{1}\right)\left(\phi_{2}-1\right)\right]=\theta_{1} /(1-\theta-\beta \theta) .
$$

The ratio of equation (6) to equation (5) equals $\phi_{2} /\left(\phi_{2}-1\right)$. This ratio must exceed 1 since $\phi_{2}$ exceeds 1 .

\section{Data and Empirical Implementation}

\section{A. Sample}

Each year since 1975 the University of Michigan's Institute for Social Research has conducted a nationally representative random sample of between 15,000 and 19,000 high school seniors between March 15 and April 30 as part of the Monitoring the Future research program. These surveys, which are described in detail by Johnston, O'Malley, and Bachman (1993), focus on the use of illegal drugs, alcohol, and cigarettes. Starting with the class of 
1976, a sample of approximately 2,400 individuals in each senior class has been chosen for followup. Individuals reporting current daily marijuana use or use of any other illegal drugs in the past 30 days in their senior year are selected with a higher probability (by a factor of 3). The 2,400 selected respondents are divided into two groups of 1,200 each; one group is surveyed on even-numbered calendar years, while the other group is surveyed on oddnumbered calendar years. As a result of this design, one group is resurveyed for the first time one year after baseline (the senior year in high school), while the other group is resurveyed for the first time two years after baseline. Subsequent followups are conducted at two year intervals for both groups .

We estimate alcohol demand functions using ten of the twenty panels formed from the high school senior surveys conducted from 1976 through 1985. We limit the panels to those in which the first followup occurred two years after baseline, so that each followup was conducted at two year intervals. The last followup in our data set, which contains approximately 12,000 persons, took place in 1989. We have between one and five observations on each person since we require information on current, past, and future consumption of alcohol. For example, the first observation on a given person pertains to the first followup with past consumption of alcohol taken from baseline and future consumption taken from the second followup. The last observation pertains to the next to the last followup with past consumption taken from the second to the last followup and future consumption taken from the last followup. Since an annual measure of consumption is used in the regressions, past consumption coincides with the second annual lag and future consumption coincides with the second annual lead. We have five observations 
for persons from the 1976 and 1977 baselines, four observations for the 1978 and 1979 baselines, three from the 1980 and 1981 baselines, two from the 1982 and 1983 baselines, and one from the 1984 and 1985 baselines.

Clearly, we are applying the rational addiction model to the demand for alcohol by teenagers and young adults. Indeed, the members of our panel are approximately age seventeen at baseline, age nineteen at the first followup, age twenty-one at the second, age twenty-three at the third, age twenty-five at the fourth, and age twenty-seven at the fifth. We already have indicated that it may be more difficult to apply rational addiction to the demand for alcohol than to the demand for cigarettes because the distribution of alcohol consumption in the population at large is more continuous than the bimodal distribution that Becker and Murphy (1988) demonstrate is likely to characterize the consumption of addictive goods. Moreover, practically all of our sample were illegal drinkers at baseline since every state has had a minimum legal age for the purchase and consumption of alcohol of at least eighteen since the 1930s.

Several factors suggest, however, that the rational addiction model of alcohol consumption may be more relevant to our sample than to a representative sample of the population of all ages and that this sample may be particularly sensitive to price. One factor is that many youths begin to drink alcohol well before the age of eighteen (for example, Rachal et al. 1980). Second and more important, illegal drug users are overrepresented in our sample, and these persons consume more alcohol than those who do not use illegal drugs (for example, Yamaguchi and Kandel 1984).4

Third and even more important, among persons eighteen years of age and older, alcohol consumption declines with age (Kenkel 1993; Manning, Blumberg, 
and Moulton 1995). Indeed, Grant et al. (1991) report that the prevalence of alcohol dependence and abuse is highest among persons aged eighteen through twenty-nine. This is almost precisely the age range in our sample. Based on data from the 1988 National Health Interview Survey, Grant et al. (1991) indicate that the prevalence rate of alcohol abuse and dependence fell from 17 percent for persons aged eighteen through twenty-nine to less than 2 percent for persons aged sixty-five and over. Moreover, the prevalence rate in the youngest age category was almost double the rate of persons aged thirty through forty-four.

The coefficient of past consumption $(\theta)$ in equation (2) measures the degree of addiction. The preceding arguments suggest that $\theta$ is likely to be larger in the Monitoring the Future panel than in a representative panel of persons of all ages. From equation (6), the larger the value of $\theta$, the larger is the long-run price effect. This is one basis for predicting that the panel is likely to be particularly sensitive to price. Another factor that leads to this prediction is that youths and young adults are likely to have lower time discount factors (higher rates of time preference for the present) than older adults. Becker, Grossman, and Murphy (1991) show that a reduction in the discount factor increases the long-run price effect.

Finally, interactions between peer pressure and addiction also predict greater price sensitivity by youths and young adults (Becker 1992). Bandwagon or peer effects are much more important in the case of youth and young adult alcohol consumption than in the case of older adult alcohol consumption. That is, youths and young adults are much more likely to drink if their peers also engage in this behavior. Initially, a fall in the price of an addictive good subject to peer pressure causes each consumer to increase his or her demand 
for the good for two reasons. There is a direct price effect and an indirect price effect operating through peer consumption. Over time, the increase in current consumption stimulates future consumption due to the reinforcement property of an addictive good. In turn, reinforcement makes the peer effect larger.

One problem with the Monitoring the Future panel is that persons who dropped out of high school prior to March of their senior year are excluded. Dropouts may have different alcohol consumption patterns than persons who remain in school. Nevertheless, the Monitoring the Future sample is the longest nationally representative panel with information on alcohol consumption in an age group with the highest rate of alcohol abuse.

\section{B. Alcoholic Beverage Prices}

Information on county identifiers at baseline and at each followup allowed us to augment the data set with alcoholic beverage prices from the Inter-City Cost of Living Index, published quarterly by the American Chamber of Commerce Researchers Association (ACCRA) for between 250 and 300 cities since the first quarter of 1968 (ACCRA various years). The ACCRA collects information on the prices of a number of consumer goods including beer, wine, and distilled spirits. In addition to prices, the ACCRA constructs a cityspecific cost of living index for each of the cities with an average for all cities in a given quarter and year equal to one.

As noted above, the baseline survey is conducted between March 15 and April 30. It takes place in the youth's high school. The followup surveys are mailed to the home addresses of respondents during the weeks of April 1 . 15. Respondents are requested to return the surveys promptly but do not 
always do so. Consequently, we assume that the annual alcohol consumption measure described in Section II.C, which pertains to consumption during the last year, reflects consumption in the first two quarters of the year in which the survey was conducted (year $t$ ) and the last two quarters of the previous year (year t-1). Thus, the current annual price of alcohol described below is computed as a simple average of the prices over these four quarters. The second annual lead and lag, which are employed extensively in the regressions in Sections III and IV are given as a simple average of the price in the first two quarters of year $t+2$ and the last two quarters of year $t+1$ (second annual lead) and as a simple average of the price in the first two quarters of year t-2 and the last two quarters of year $t-3$ (second annual lag).

The price assigned to each person in each of the four quarters employed to compute the current price is the price in the ACCRA survey city nearest the person's county of residence. Similar comments apply to the computation of lags and leads of the price. For persons with different county residence codes in survey years $t$ and $t+2$, prices from the third quarter of year $t$ through the fourth quarter of year $t+1$ are computed as simple averages of the prices in each county. Since much of the cross-sectional variation in alcoholic beverage prices is due to variations in state excise tax rates on these beverages, persons are never matched to ACCRA cities outside their state of residence. This results in the deletion of some observations because not all states are represented in a given ACCRA survey.

Data on the consumption of specific alcoholic beverages (beer, wine, and distilled spirits) are not collected for four-fifths of the Monitoring the Future respondents. Therefore, the price of beer is used as the measure of the price of alcohol. This price is selected because beer is the most heavily 
consumed alcoholic beverage and because beer is the beverage of choice among teenagers and young adults. The specific price is the price of a six-pack (six-12 ounce cans) of Budweiser or Schlitz. ${ }^{5}$ All quarterly nominal beer prices are averaged over the four relevant quarters to obtain the current annual nominal price of beer and the second annual leads and lags of the price. These prices are converted to real prices by dividing them by a yearand city-specific cost of living index. This index is the ACCRA city-specific cost of living index multiplied by the quarterly CPI for the U.S. as a whole $(1982-84=1)$ and then averaged over the four relevant quarters.

\section{Measurement of Variables}

Table 1 contains definitions, means, and standard deviations of variables that are employed in the regression analyses in Section III. They are based on the sample of 21,420 person-years or person-followups that results by deleting persons who failed to respond to at least three consecutive questionnaires (including baseline) and by deleting observations for which the number of drinks of alcohol in the past year, the current real price of beer, and current real annual earnings are missing. Given three observations per person on average, there are approximately 7,140 respondents in the final sample.

There are no missing values for age, male, black, and other race/ethnicity. Missing values for the other variables listed in the table are replaced by panel- and strata-specific means. Recall that there are two strata for each panel. One consists of persons who used marijuana daily at baseline or used another illegal drug during the past month at baseline, and the other consists of persons who did not exhibit these illegal drug use 
patterns at baseline. The means and standard deviations in the table are weighted to correct for oversampling--by a factor of three--persons in the illegal drug stratum. In particular, they are weighted by the inverse of the probability of selection, which is equivalent to multiplying values of a given variable from the illegal drug stratum by one-third. Thus, the means and standard deviations in the table are representative of those in the population.

The number of drinks of alcohol consumed in the past year is the dependent variable in all regressions in Section III. This variable is given by the product of the number of drinking occasions during the last 12 months and the number of drinks consumed on a typical drinking occasion. Both components are measured with error. The number of drinking occasions is an ordered categorical variable with 7 outcomes: 0 occasions, $1-2$ occasions, $3-5$ occasions, $6-9$ occasions, 10-19 occasions, $20-39$ occasions, and 40 or more occasions. It is converted into a continuous variable by assigning midpoints to the closed intervals and a value of 50 to the open-ended interval.

The number of drinks on a typical drinking occasion is inferred from the response to the question: "On the occasions that you drink alcoholic beverages, how often do you drink enough to feel pretty high?" The response categories are none of the occasions, few of the occasions, half of the occasions, most of the occasions, and nearly all of the occasions. ${ }^{6}$ We assume that the second response category corresponds to 25 percent of all occasions, that fourth corresponds to 75 percent of all occasions, and that the fifth corresponds to 100 percent of all occasions. We also assume that 4 drinks must be consumed to feel pretty high. Persons in the first response category are assumed to consume 1.5 drinks on a typical drinking occasion. 
Persons in the second category are assumed to consume $.75 * 1.5+.25 * 4=2.125$ drinks on a typical occasion. Persons in third category are assigned a value of $.5 * 1.5+.5 * 4=2.75$. Persons in the fourth category are assigned a value of $.25 * 1.5+.75 * 4=3.375$, and persons in the fifth category are given a value of 4 drinks on a typical occasion.

Clearly, the number of drinking occasions is measured objectively, while the indicator of the number of drinks on a typical drinking occasion is subjective. Note that the results presented in Section III are not sensitive to alternative assumptions made about the number of drinks that must be consumed to feel pretty high. For example, the basic estimates did not change when this number was allowed to be smaller for females than for males.

The minimum legal drinking age for the purchase and consumption of low alcohol beer is a partial determinant of the full price of alcohol, especially for underage youths. ${ }^{7}$ Since no state has ever had a legal drinking age greater than twenty-one, the drinking age is multiplied by a dichotomous variable that equals one for persons twenty-one years of age or younger. In fact, since precise birth dates are not available and respondents could have changed from illegal drinkers to legal drinkers during the past year, the variable just mentioned takes the form of a dichotomous indicator for the first two followups. As previously indicated, the members of the panel are approximately nineteen years old at the first followup and twenty-one years old at the second followup. Along the same lines, the four age variables in Table 1 really are dichotomous indicators for the first, second, third, and fourth followups, respectively.

In addition to the own-state minimum legal drinking age, a dichotomous indicator equal to one if a respondent resides in a county within 25 miles of 
a state with a lower legal drinking age is employed as a regressor. This variable is equal to zero if the respondent does not live in a county within 25 miles of another state or if the drinking age in his or her state is as low or lower than that in nearby states. It is interacted with the dichotomous indicator for persons whose age is less than or equal to twenty-one for the same reason that the drinking age is interacted with this indicator. The border age variable is included in the model to capture potential border crossings by youths from states with high drinking ages to nearby lower age states to obtain alcohol. With the own-state legal drinking age held constant, the coefficient of the border age variable in the demand function should be positive.

We have discussed the modeling of legal drinking age effects in detail in previous research (Grossman, Coate, and Arluck 1987; Coate and Grossman 1988; Laixuthai and Chaloupka 1993). Here we note that our specification recognizes that it is likely to be easier (less costly) for a nineteen year old to obtain alcohol in a state with a drinking age of twenty than in one with a drinking age of twenty-one. We also note that peers are an important source of alcohol for youths, particularly in a college setting. Thus, twenty-one year olds in a state with a drinking age of twenty-one may have less access to "free" alcohol than twenty-one year olds in a state with a drinking age of eighteen, nineteen, or twenty.

A variety of independent variables were constructed from the demographic and socioeconomic information collected in the surveys. These include sex; race (black or other); age (see above); real annual earnings; years of formal schooling completed; college student status (full-time, half-time, or less than half-time); work status (full-time, part-time, or unemployed); 
religious participation (infrequent or frequent); marital status (married, engaged, or separated or divorced); and the respondent's number of children. Finally, all models include dichotomous variables for nine of the ten cohorts (the high school senior classes of 1976 through 1984). The time-varying variables serve as proxies for life-cycle variables that affect the marginal utility of current consumption.

\section{Estimation Issues}

Given the nature of the panel, we estimate equation (2) with the second lag of the annual number of drinks of alcohol as the measure of past consumption and the second lead of the annual number of drinks of alcohol as the measure of future consumption. Since past consumption and future consumption are endogenous, the equation is fitted by two-stage least squares (TSLS). The instruments consist of the exogenous variables in the model, the second lag of the annual real beer price, the second lead of the annual real beer price, the second annual lags of the two measures pertaining to the legal drinking age (legal drinking age*age $\leq 21$ and lower border drinking age indicator*ages21), and the second leads and the second lags of all timevarying socioeconomic variables. These include real annual earnings, years of formal schooling completed, college student status, work status, religious participation, marital status, and number of children.

The second leads of the two measures pertaining to the legal drinking age are not used as instruments because the values of these two variables are zero except at the first followup. The second leads and second lags of all time-varying socioeconomic variables are valid instruments for reasons given in Section II. Moreover, the second lead and lag of the real beer price and 
the second lag of the drinking age do not provide enough explanatory power to obtain reliable parameter estimates. Probably this is because in a given year, the real beer price and the drinking age measures vary only among counties, while past and future consumption vary among persons.

At the first followup, second lags of socioeconomic variables pertain to baseline data. For this followup, the second lag of years of formal schooling completed equals 11 for all respondents, and the second lags of the full-time, half-time, and less than half-time college student status indicators all are equal to zero. The second lag of work status is taken from a baseline question on average hours of work per week during the school year. ${ }^{9}$ High school seniors who do not work at all during the school year are assumed to be not in the labor force rather than unemployed. The second lag of earnings as of the first followup equals the sum of income from work during the school year and other sources such as allowances and summer jobs. ${ }^{10}$

A problem with the use of leads and lags of the socioeconomic variables as instruments is that these variables may not be exogenous. While plausible arguments can be made for the endogeneity of all of them, the real issue is which ones are most likely to be caused by alcohol consumption or correlated with the disturbance term in the structural alcohol demand function given by equation (2). In our view, religious participation, marital status, and number of children are more likely to fall into the latter category. ${ }^{11}$ Therefore, demand functions are obtained with and without these variables.

In interpreting the estimates in Section III, one should bear in mind that both consumption and price are subject to measurement error. The number of drinks of alcohol consumed in the past year is measured with error for reasons given in Section II.C. In particular, almost 38 percent of all cases 
(unweighted) fall into the open-ended frequency category of 40 or more drinking occasions in the past 12 months. Clearly, the magnitudes of price elasticities will be affected by the number of drinking occasions assigned to this category. Thus, it is more important to focus on the relative magnitudes of the elasticities (the long-run elasticity relative to the short-run elasticity or relative to the elasticity that ignores addiction) than on the absolute magnitudes of the elasticities. Given the objective nature of the drinking frequency measure relative to the measure of the number of drinks on a typical drinking day and the large percentage of cases in the open-ended drinking frequency category, we treat the probability of frequent drinking as a separate outcome in Section IV. This is preferable to assigning alternative arbitrary values to the open-ended category.

The real price of beer contains measurement error for several reasons. First, the price prior to the first quarter of 1982 was obtained by backcasting, as described in note 5 . Second, the price data pertain to the ACCRA survey city nearest the respondent's county of residence rather than to the city or town in which the respondent actually resides. Third, the cost of living index reflects expenditure patterns of midmanagement (middle-income) households. These patterns may differ from those of teenagers and young adults. Random measurement error in an independent variable biases its coefficient and $t$-ratio toward zero. Thus, the price coefficients and associated t-ratios in Section III are conservative lower-bound estimates. ${ }^{12}$ Despite the oversampling of illegal drug users at baseline, unweighted regressions are obtained. Maddala (1983, pp. 170-171) shows that this is the appropriate procedure in the case of exogenous stratification (oversampling on the basis of an exogenous variable in a regression model). In particular, if 
$w_{j}$ is the inverse of the sampling fraction for the $j$ th stratum, there is no justification for a weighted least squares procedure in which $\left(w_{j}\right)^{1 / 2}$ is the weight. The reason is that in regression analysis weighting is employed to produce efficient estimates rather than to produce consistent estimates. There is no reason why the drawing of non-equiproportionate samples from different strata should introduce heteroscedasticity such that the residual variance is $\sigma^{2} / w_{j}$, where $\sigma^{2}$ is a constant.

Maddala (1983, pp.171-173) also shows that it is appropriate to weight by $\left(w_{j}\right)^{1 / 2}$ in the case of endogenous stratification (oversampling on the basis of the dependent variable in a regression model). In our case, the oversampling is based on a variable--illegal drug use--that does not enter the regression model as a dependent or independent variable. Perhaps an argument could be made for weighting because illegal drug use is positively related to alcohol use. But Maddala's model assumes that slope coefficients are the same in the two strata. As we noted in Section II.A, the rational addiction model of alcohol consumption may be more relevant for illegal drug users than for non-users. For large enough samples, this could be investigated by obtaining separate regressions for each stratum. ${ }^{13}$ But the stratum generated by persons who used illegal drugs at baseline does not account for a sufficient percentage of cases (person-years) to obtain reliable parameter estimates.

Our preferred strategy is to pool the two strata and fit unweighted regressions. The resulting coefficients essentially are averages for the two strata, with more weight given to the illegal drug stratum than would be the case in a random sample. This is appropriate in light of our focus on rational addiction behavior and in light of the absence of empirical estimates of alcohol demand functions that employ micro panel data. ${ }^{14}$ We did, however, 
experiment with weighted regressions and found that they were very similar to the unweighted estimates in Section III.

\section{Empirical Results}

Table 2 contains standard alcohol demand functions that ignore addictive behavior. In particular, past and future consumption are excluded from these estimates. The regression in column 1 omits religious participation, marital status, and number of children, while the regression in column 2 includes these variables.

The most important findings in these regressions are the negative and significant price and legal drinking age effects and the positive and significant border age effect. The magnitude, but not the significance, of the price coefficient is sensitive to the inclusion of religious participation, marital status, and number of children. In particular, the price coefficient is cut in half when these variables are added to the set of regressors. At the weighted sample means of price and consumption, the price elasticity of demand equals -0.38 in the first regression and -0.20 in the second regression. ${ }^{15}$ The first estimate may be influenced by omitted variables bias, while the second may be influenced by simultaneous equations bias. Therefore, we regard the average of these two figures of -0.29 as the benchmark price elasticity that emerges from a demand function for the number of drinks of alcohol in the past year that ignores addictive behavior.

Table 3 tests the rational addiction model directly by estimating the structural demand function given by equation (2). The first two columns contain two-stage least squares (TSLS) regressions in which past consumption (the second annual lag of consumption) and future consumption (the second 
annual lead of consumption) are endogenous. Religious participation, marital status, and number of children are excluded from the first regression and included in the second. As indicated in Section II.D, the instruments for past and future consumption are all the exogenous variables in the model, the second lag of the beer price, the second lead of the beer price, the second lags of the two measures pertaining to the legal drinking age, and the second lags and leads of all time-varying socioeconomic variables. The last two columns contain the corresponding ordinary least squares (OLS) regressions. The table also contains F-ratios resulting from Wu's (1973) test of the hypothesis that OLS estimates are consistent.

In the model with religious participation, marital status, and number of children, the consistency of OLS is rejected. In the model without these variables, the wu test is inconclusive. The F-ratio of 3.18 is significant at the 5 percent level but not at the 1 percent level. Given these results and the potential endogeneity of religious participation, marital status, and number of children, it is useful to consider the OLS regressions as well as the TSLS regressions in evaluating the findings.

The estimated effects of past and future consumption on current consumption are significantly positive in the four regressions in Table 3 , and the estimated price and legal drinking age effects are significantly negative in all cases. The positive and significant past consumption coefficient is consistent with the hypothesis that alcohol consumption is an addictive behavior. The positive and significant future consumption coefficient is consistent with the hypothesis of rational addiction and inconsistent with the hypothesis of myopic addiction. The sum of the past and future consumption coefficients is always smaller than one. This means that the long-run, short- 
run, and temporary price effects, which are discussed in more detail below, are negative.

Clearly, the estimates indicate that alcohol consumption is addictive in the sense that past and future changes significantly impact current consumption. This evidence is inconsistent with the hypothesis that alcohol consumers are myopic. Still, the estimates are not fully consistent with rational addiction because the estinates of the discount factor $(\beta)-$ given by the ratio of the coefficient of future consumption to the coefficient of past consumption--are implausibly high. The implied discount factor is 2.58 in the first regression, 1.26 in the second regression, 1.37 in the third regression, and 1.34 in the fourth regression. These discount factors correspond to negative interest rates of -61 percent, -20 percent, -27 percent, and -26 percent, respectively.

The standard errors of the four estimates of the discount factor are $0.76,0.23,0.04$, and 0.04 , respectively. ${ }^{16}$ The estimates of $2.58,1.37$, and 1.34 are significantly greater than one ( $t$-ratios equal $2.08,9.25$, and 8.50 , respectively). The estimate of 1.26 not only is not significantly greater than one (t-ratio equals 1.13), but it is also not significantly greater than 0.95 (t-ratio equals 1.35). A discount factor of 0.95 corresponds to a quite reasonable interest rate of 5 percent. When this discount factor is imposed a priori, the price and legal drinking age coefficients are extremely close to the corresponding coefficients in Table 3 . These results, combined with the detailed analysis in Becker, Grossman, and Murphy (1994), suggest that data on alcohol consumption or cigarette smoking are not rich enough to pin down the discount factor with precision even if the rational addiction model is accepted. 
Table 4 uses the estimates from Tables 3 to compute the elasticity of the annual number of drinks of alcohol with respect to the various price changes defined in Section I at the weighted sample means of price and consumption [see equations $(4 a-c),(5)$, and (6)]. The long-run elasticity ranges from -0.26 to -1.26 (average equals -0.65). The short-run elasticity ranges from -0.18 to -0.86 (average equals -0.41 ). The ratio of the long-run elasticity to the corresponding short-run elasticity is more stable. It varies from 1.44 to 1.77 (average equals 1.60). This ratio should be compared to a ratio of approximately 2.00 in the case of rational addiction demand functions for cigarettes (Chaloupka 1991; Becker, Grossman, and Murphy 1994) Becker, Grossman, and Murphy (1991) show that the ratio of the long-run price elasticity to the short-run price elasticity rises as the degree of addiction, measured by the coefficient of past consumption, rises. Thus, our results suggest that alcohol consumption is somewhat less addictive than cigarette smoking. Nevertheless, the long-run elasticity of demand for the number of drinks of alcohol in the past year is substantially larger than the short-run elasticity. Hence, the long-run reduction in consumption caused by a permanent price increase due, for example to a hike in the federal excise tax rate on beer, would be considerably larger than the reduction in consumption after one year.

The average long-run price elasticity of -0.65 also is more than twice as large as the benchmark price elasticity of -0.29 that emerge from the demand functions in Table 2 that ignore addiction. Indeed, the average shortrun elasticity is almost 40 percent larger than the benchmark elasticity. Consequently, forecasts of increases in tax revenue due to excise tax hikes would be considerably overstated and forecasts of reductions in consumption 
would be considerably understated if they were based on the benchmark elasticity.

With regard to the temporary price elasticities, a 10 percent reduction in the current price causes consumption to rise by between 1 and 1.5 percent. A 10 percent reduction in current price also leads to an increase of between 0.3 percent and 0.7 percent in next period's consumption and to a 0.4 to 1.2 percent increase in the previous period's consumption. These negative cross price effects are inconsistent with nonaddictive behavior, and the negative future price effect is inconsistent with myopic behavior. The future price elasticity exceeds the past price elasticity because the estimate of the discount factor always is larger than one.

In Table 5 we examine the robustness of the price and consumption effects by estimating a two-stage least squares fixed-effects model. Using this technique, we transforms all time-varying variables into deviations from person-specific means and delete time-invariant variables from the regressions. This approach is equivalent to including a dummy variable for each person in an untransformed specification. It controls for unobserved heterogeneity, which may be correlated with religious participation, marital status, and the number of children. Thus the fixed-effects specification is an alternative way to control for the forces captured by these variables, and they are omitted. Since the wu test strongly rejects the consistency of oLs (F-ratio equals 9.22), only the TSLS coefficients are presented in the table. 17

The results in Table 5 strongly confirm those in Table 3 . The past and future consumption coefficients are positive and significant, while the current price coefficient is negative and significant. The long-run price 
elasticity of -.54 is substantial. As pointed out in Section II.D, the real price of beer contains random measurement error for a variety of reasons. The downward biases in the price coefficient and its t-ratio due to this factor are exacerbated in the fixed-effects model (Griliches 1979; Griliches and Hausman 1986). Thus, the estimates in Table 5 are not necessarily superior to those in Table 3. Taken together, however, the two tables underscore the stability and validity of our findings.

Moore and Cook (1995) provide further evidence in support of a rational model of alcohol addiction in the National Longitudinal Survey of Youth. The members of that survey are approximately the same age as the members of Monitoring the Future. Moore and Cook report positive effects of past and future consumption on current consumption and a negative effect of the state beer tax on consumption. Their study differs from ours because they have only two observations on current consumption, because they do not measure the cost of alcohol by the city-specific beer price, because the beer tax coefficient is estimated somewhat imprecisely, and because the long-run beer tax effect is not always negative. Moreover, their main focus is on habit formation via the effects of past variables rather than on rational addiction.

\section{Participation in Frequent Drinking}

In this section we examine the determinants of participation in frequent drinking. Frequent drinkers are those who report forty or more drinking occasions in the past year. Recall that this is the upper open-ended interval in the drinking frequency item on the questionnaire. Thirty-three percent of all cases (weighted) fall into this category, It is particularly important to focus on the frequent drinking outcome because it was assigned a value of 50 
occasions in the past year in computing the annual number of drinks. Clearly, the elasticities reported in the last section would be affected if a different value had been used.

Linear probability models are obtained. In principle, standard errors of regression coefficients should be corrected based on White's (1980) algorithm. In fact, the correction had almost no impact on the standard errors in preliminary calculations, which is not surprising given the large sample size. Thus, t-ratios are based on uncorrected standard errors. The two-stage least squares estimates correspond to Heckman and MaCurdy's (1985) simultaneous equations linear probability model.

As in Section III, we begin with regressions of the probability of forty or more annual drinking occasions that ignore addictive behavior by excluding past and future consumption. The results (not shown) mirror those in Table 2. In particular, the price and legal drinking age effects are negative and significant, while the border age effect is positive and significant. The magnitude, but not the significance, of the price coefficient is sensitive to the inclusion of religious participation, marital status, and number of children. At the weighted sample means of price and participation in frequent drinking, the price elasticity of demand equals -0.44 in the regression without these variables and -0.22 in the regression with them. The average of these two figures of -0.33 may be regarded as the benchmark elasticity for participation in frequent drinking that emerges from a demand function that ignores addiction.

Tables 6 and 7 contain structural rational addiction demand functions for the probability of frequent drinking. This probability is directly related to past and future consumption. Two approaches are taken to measuring 
past and future consumption. The variables in Table 6 (past percentage high and future percentage high) are based on the response to the question: "On the occasions that you drink alcoholic beverages, how often do you drink enough to feel pretty high?" The response categories are none of the occasions, few of the occasions, half of the occasions, most of the occasions, and nearly all of the occasions. Previously, we used these categories to estimate the number of drinks on a typical drinking occasion by assuming that 4 drinks must be consumed to feel pretty high. Here we simply scale them as 0 percent, 25 percent, 50 percent, 75 percent, and 100 percent. This is a more flexible indicator than our estimate of the number of drinks consumed on a typical drinking occasion because it makes no assumption about the number of drinks required to feel pretty high. Moreover, it is reported and measured independently of drinking frequency. Past percentage high (the second lag of the scaled variable just defined) has a weighted mean of 32 percent and future percentage high (the second lead) has a weighted mean of 28 percent.

The disadvantage of the estimates in Table 6 is that they cannot be used to compute long-run participation price elasticities--elasticities which can be compared to those that ignore addiction. Therefore, in Table 7 we use the past and future probabilities of frequent drinking (or dichotomous indicators in the OLS models) as measures of past and future consumption. Taken together, the estimates in Tables 6 and 7 can be viewed as first-order approximations to structural demand functions for participation in an addictive behavior. As in Section III, past and future consumption are endogenous in the TSLS regressions. The instruments are the same as in that section.

Regardless of whether the demand functions are obtained by TSLS or by 
OLS, the estimated effects of past and future percentage high on the probability of current participation in frequent drinking are significantly positive in Table 6 , and the price and legal drinking age effects are significantly negative. Similar results emerge from Table 7 , except that the price coefficient is significant at the 10 percent level on a one-tailed test but not at the 5 percent level in columns 2 and 4 . The long-run price elasticity of participation in frequent drinking is -1.18 in the first regression in Table $7,-0.27$ in the second regression, -0.63 in the third, and -0.32 in the fourth. The average elasticity of -0.60 is approximately twice as large as the elasticity that ignores addiction of -0.33 . These findings provide rather strong support for the rational addiction approach to participation in frequent drinking. 


\section{REFERENCES}

American Chamber of Commerce Researchers Association. Inter-City Cost of Living Index. Louisville, Kentucky: American Chamber of Commerce Researchers Association, various years.

Becker, Gary S. "Habits, Addictions, and Traditions." Kyklos, 45 (1992), $327-346$.

Becker, Gary S.; Grossman, Michael; and Murphy, Kevin M. "An Empirical Analysis of Cigarette Addiction." American Economic Review, 84 , No. 3 (June 1994), 396-418.

Becker, Gary S.; Grossman, Michael; and Murphy, Kevin M. "Rational Addiction and the Effect of Price on Consumption." American Economic Review, 81, Nio. 2 (May 1991), 237-241.

Becker, Gary S., and Murphy, Kevin M. "A Theory of Rational Addiction." Journal of Political Economy, 96, No. 4 (August 1988), 675-700.

Chaloupka, Frank J. "Economic Models of Habitual and Addictive Behavior: Empirical Applications to Cigarette Smoking." In Volume 3 of Advances in Behavioral Economics, edited by Leonard Green. Greenwich, Connecticut: JAI Press, Inc., forthcoming.

Chaloupka, Frank J. "Rational Addictive Behavior and Cigarette Smoking." Journal of Political Economy, 99, No. 4 (August 1991), $722-742$.

Chaloupka, Frank J.; Saffer, Henry; and Grossman, Michael. "Alcohol-Control Policies and Motor-Vehicle Fatalities." Journal of Legal Studies, 22, No. 1 (January 1993), 161-186.

Coate, Douglas, and Grossman, Michael. "Effects of Alcoholic Beverage Prices and Legal Drinking Ages on Youth Alcohol Use." Journal of Law and Economics, 31, No. 1 (April 1988), 145-171. 
Grant, Bridget F.; Hartford, Thomas C.; Chou, Patricia; Pickering, Roger;

Dawson, Deborah A.; Stinson, Frederick S.; and Noble, John. "Prevalence of DSM-III-R Alcohol Abuse and Dependence." Alcohol Health \& Research Wor1d, 15, No. 1 (1991), $91-96$.

Griliches, Zvi. "Sibling Models and Data in Economics: Beginnings of a Survey." Journal of Political Economy, 87, No. 5, Part 2 (October 1979), S37-S64.

Griliches, Zvi, and Hausman, Jerry A. "Errors in Variables in Panel

Data." Journal of Econometrics, 31, No. 1 (February 1986), 93 -

118 .

Grossman, Michael. "The Economic Analysis of Addictive Behavior." In Economic and Socioeconomic Issues in the Prevention of Alcohol-Related Problems, edited by Gregory Bloss and Michael Hilton. National Institute on Alcohol Abuse and Alcoholism Research Monograph 25. NIH Publication No. 93-3513. Washington, D.C.: U.S. Government Printing Office 1993, 91-124.

Grossman, Michael; Coate, Douglas; and Arluck, Gregory M. "Price Sensitivity of Alcoholic Beverages in the United States." In Control Issues in Alcohol Abuse Prevention: Strategies for States and Communities, edited by Harold D. Holder. Greenwich, Connecticut: JAI Press, Inc., 1987, 169-198.

Heckman, James J. "Sample Selection Bias as a Specification Error." Econometrica, 46, No. 1 (January 1979), 153-161.

Heckman, James J., and MaCurdy, Thomas E. "A Simultaneous Equations Linear Probability Model." Canadian Journal of Economics, 18, No. 1 (February 1985), $28-37$. 
Johnston, Lloyd D.; O'Malley, Patrick M.; and Bachman, Jerald G. National Survey Results from the Monitoring the Future Study, 1975-1992. NIH Publication No. 93-3597/98. Washington, D.C.: U.S. Government Printing Office, 1993.

Keeler, Theodore E.; Hu, Teh-wei; Barnett, Paul G.; and Manning, Willard G. "Taxation, Regulation, and Addiction: A Demand Function for Cigarettes Based on Time-Series Evidence." Journal of Health Economics, 12 , No. 1 (Apri1 1993), 1-18.

Kenke1, Donald S. "Drinking, Driving, and Deterrence: The Social Costs of Alternative Policies." Journal of Law and Economics, 36, No. 2 (October 1993), $877-913$.

Kenkel, Donald S., and Ribar, David C. "Alcohol Consumption and Young Adults' Socioeconomic Status." Brookings Papers on Economic Activity: Microeconomics. Washington, D.C.: The Brookings Institution, 1994, 119 175 .

Kmenta, Jan. Elements of Econometrics. Second Edition. New York: Macmillan Pub1ishing Company, 1986.

Laixuthai, Adit, and Chaloupka, Frank J. "Youth Alcohol Use and Public Policy." Contemporary Policy Issues, 11, No. 4 (October 1993), 70-81. Leung, Siu Fai., and Phelps, Charles E. "'My Kingdom for a Drink...?' A Review of the Price Sensitivity of Demand for Alcoholic Beverages." In Economic and Socioeconomic Issues in the Prevention of Alcohol-Related Problems, edited by Gregory Bloss and Michael Hilton. National Institute on Alcohol Abuse and Alcoholism Research Monograph 25. NIH Publication No. 93-3513. Washington, D.C.: U.S. Government Printing Office 1993, 1-32. 
Maddala, G.S. Limited Dependent and Qualitative Variables in Economics. Cambridge, England: Cambridge University Press, 1983.

Manning, Willard G.; Blumberg, Linda; and Moulton, Lawrence, H. "The Demand for Alcohol: the Differential Response to Price." Journal of Health Economics, 14, No. 2 (June 1995), 123-148.

Miller-Tutzauer, Carol; Leonard, Kenneth E.; and Windle, Michael. "Marriage and Alcohol Use: A Longitudinal Study of 'Maturing Out'." Journal of Studies on Alcohol, 52 (September 1991), 434-440.

Nickel1, Stephen. "Biases in Dynamic Models with Fixed Effects." Econometrica, 49, No. 6 (November 1981), 1417-1426.

Moore, Michael J., and Cook, Philip J. "Habit and Heterogeneity in the Youthful Demand for Alcohol." National Bureau of Economic Research Working Paper No. 5152, June 1995.

Moulton, Brent R. "An Illustration of a Pitfall in Estimating the Effects of Aggregate Variables on Micro Units." Review of Economics and Statistics, 72, No. 2 (May 1990), 334-338.

Rachal, J. Valley; Guess, L. Lynn; Hubbard, Robert L.; Maisto, Stephen A; Cavanaugh, Elizabeth R.; Waddell, Richard; and Benrud, Charles H. "The Extent and Nature of Adolescent Alcohol Abuse: The 1974 and 1978 National Sample Surveys." Prepared for the National Institute on Alcohol Abuse and Alcoholism. Springfield, Virginia: U.S. National Technical Information Service, 1980.

Rimm, Eric B.; Giovannucci, Edward L.; Willett, Walter C.; Colditz, Graham A.; Ascheria, Alberto; Rosner, Bernard; and Stamfer, Meir J. "Prospective Study of Alcohol Consumption and Risk of Coronary Disease in Men." Lancet, 338 (August 24, 1991), 464-468. 
White, Halbert. "Heteroscedasticity-Consistent Covariance Matrix Estimator and a Direct Test for Heteroscedasticity." Econometrica, 48, No. 4 (May 1980), 817-838.

Wu, De-Min. "Alternative Tests of Independence between Stochastic Regressors and Disturbances." Econometrica, 41, No. 4 (July 1973), 733-750.

Yamaguchi, Kazuo, and Kande1, Denise B. "Patterns of Drug Use from Adolescence to Young Adulthood: III. Predictors of Progression." American Journal of Public Health, 74, No. 7 (July 1984), 673-681. 


\section{FOOTNOTES}

Research for this paper was supported by grant 5 R01 AA08359 from the National Institute on Alcohol Abuse and Alcoholism to the National Bureau of Economic Research. We are extremely grateful to Patrick M. O'Malley, Senior Research Scientist at the University of Michigan's Institute for Social Research, for providing us with the Monitoring the Future panels and for agreeing to attach county identifiers to our tapes. We also are extremely grateful to Jerome J. Hiniker, Senior Research Associate at ISR, for creating the computer programs that produced these tapes. Part of the paper was written while Grossman was a visiting scholar at the Catholic University of the Louvain in Belgium, and he wishes to acknowledge the financial support provided by that institution. We are indebted to Gary S. Becker, Randall K, Filer, Robert J. Kaestner, Theodore E. Keeler, Donald S. Kenke1, Lee A. Lillard, John Mullahy, Kevin M. Murphy, Jon P. Nelson, and Gary A. Zarkin for helpful comments and suggestions. Preliminary versions of the paper were presented at the 1995 meeting of the American Economic Association and the 1994 meeting of the Western Economic Association and at seminars at Brigham Young University, the Catholic University of the Louvain, Charles University in Prague, the University of Chicago, Erasmus University in Rotterdam, the Rand Corporation, the Stockholm School of Economics, and the United States Military Academy at West Point. We are indebted to the participants in those meetings and seminars for comments and suggestions. Finally, we wish to thank Patricia De Vries, Hadassah Luwish, Geoffrey Joyce, Sandy Grossman, and Esel Yazici for research assistance. This paper has not undergone the review accorded official NBER publications; in particular, it has not been submitted for approval by the Board of Directors. 
${ }^{1}$ See Grossman (1993) and Chaloupka (forthcoming) for more detailed discussions of empirical applications of economic models of addictive behaviors. These reviews consider both myopic and rational applications and both published and unpublished studies.

${ }^{2}$ Equation ( 1 ) assumes that the rate of depreciation on the addictive stock is equal to one, so that the stock is replaced by lagged consumption $\left(C_{t-1}\right)$ in the current period utility function. In preliminary estimation, we specified a model with a rate of depreciation smaller than one. The empirical results for that model were very similar to those presented in section III. Put differently, we could not reject the hypothesis that the rate of depreciation is equal to one.

${ }^{3}$ Rimm et al. (1991) and others find that moderate alcohol consumption lowers the risk of coronary heart disease in men. It does not follow that this type of consumption is an example of beneficial addiction. The reason is that moderate alcohol consumption may lead to such negative outcomes as strokes and motor vehicle accidents.

${ }^{4}$ The positive correlation between alcohol and illegal drug use may reflect an omitted "third" variable such as risk or time preference. Clearly, it does not imply that the two goods are complements.

${ }^{5}$ The ACCRA did not collect beer prices prior to the first quarter of 1982. To obtain a complete series, we regressed the ACCRA beer price in nominal terms on the sum of the state and federal excise tax on a six-pack of beer in nominal terms; the quarterly U.S. beer price index $(1982-84=1)$, which is part of the U.S. Bureau of Labor Statistics' Consumer Price Index; the ACCRA city-specific cost of living index multiplied by the quarterly CPI 
for the U.S. as a whole $(1982-84=1)$; and dichotomous variables for the first three quarters of a given year. We then backcasted prices for quarters prior to the first quarter of 1982 based on the regression coefficients and the values of the independent variables.

${ }^{5}$ Four-fifths of the sample are asked the above question. The other onefifth is asked: "When you drink alcoholic beverages, how high do you usually get?" The responses are not at all high, a little high, moderately high, and very high. The responses to these two questions are made compatible by treating persons who usually get very high as persons who drink enough to feel pretty high on nearly all drinking occasions, persons who usually get moderately high as persons who get pretty high on half of all drinking occasions, and persons who get a little high as persons who get pretty high on few of all drinking occasions.

${ }^{7}$ Like the current annual price of beer, the legal drinking age is an annual average of quarterly values for the first two quarters of the survey year and the last two quarters of the preceding year. The construction of this variable also accounts for the grandfather clauses many states adopted when raising their legal ages for all alcoholic beverages to 21 years to comply with the Federal Uniform Drinking Age Act of 1984. Similar variables were constructed for high alcohol content beer and for distilled spirits. The three series are extremely highly correlaced, and the choice of the drinking age variable has little impact on the resulting estimates. For more details on the construction of the drinking age measure, see Chaloupka, Saffer, and Grossman (1993).

${ }^{8}$ Full-time work status and full-time college student status are not mutually exclusive categories in theory or in the followup questionnaires. 
${ }^{9}$ Full-time workers at baseline are students who work more than 20 hours per week during the school year.

${ }^{10}$ The only income question in the followup surveys pertains to own earnings .

${ }^{11}$ For evidence that marriage causes reductions in alcohol consumption, see Miller-Tutzauer, Leonard, and Windle (1991). For evidence that heavy drinking lowers the probability of marriage, see Kenkel and Ribar (1994).

${ }^{12}$ An additional source of error in the future price arises because the variable employed assumes that respondents who move fully anticipate the move. For a detailed discussion of the effects of measurement error in future price on rational addiction estimates of cigarette demand functions, see Becker, Grossman, and Murphy (1994). Moulton (1990) argues that t-ratios of coefficents of aggregate variables in micro regressions are biased downward if the disturbances in the regression are correlated among persons who live in the same area. This assumes, however, that the aggregate variable is measured without error.

${ }^{13}$ These estimates would have to be corrected for sample selection using Heckman's (1979) methodology. Identification by means other than the nonlinear relationship between the inverse of the Mills ratio and the regressors is highly problematic.

${ }^{14}$ For similar reasons, we do not distinguish between participation in alcohol consumption and consumption given participation. Since only 8 percent of all values of the number of drinks in the past year equal zero, this distinction does not appear to be important at the empirical level.

${ }^{15} \mathrm{All}$ elasticities in this section and the next one are computed at the 
weighted sample means of price and consumption. Elasticities computed at the unweighted sample means are similar.

${ }^{16}$ Let $a$ be the coefficient of past consumption, b be the coefficient of future consumption, $v_{a}$ be the variance of $a, v_{b}$ be the variance of $b$, and $c_{a b}$ be the covariance between $a$ and $b$. Then the variance of $b / a$ is given by

$$
a^{-2} v_{b}+b^{2} a^{-4} v_{a}-2 b a^{-3} c_{a b}
$$

For a derivation, see Kmenta (1986, p. 486).

${ }^{17} \mathrm{Although}$ the model in Table 5 contains the same time-varying regressors as the first model in Table 3 , it is not surprising that the wu test decisively rejects OLS in the former table but not the latter. Nickell (1981) shows that fixed-effects OLS estimation produces a negative bias and inconsistency in the coefficient of the lagged dependent variable in the absence of serial correlation. Using his techniques, one can demonstrate that the coefficients of past and future consumption are understated in the OLS fixed-effects model. Indeed, we obtain negative past and future consumption coefficients when this procedure is used. 
Table 1

Definitions, Means, and Standard Deviations of Variables ${ }^{a}$

Annual number of drinks of alcohol $(60.630,49.210)$

Price

$(2.789,0.282)$

Legal drinking age*age $\leq 21$

$(11.992,8.405)$

Lower border drinking age indicator*age $\leq 21$

$(0.096,0.257)$

Age 19

$(0.333,0.411)$

Age 21

$(0.276,0.390)$

Age 23

$(0.199,0.348)$

Age 25

$(0.131,0.293)$

Male

$(0.449,0.443)$

Black

(0.094, 0.254)

other race/ethnicity

$(0.070,0.223)$
Number of drinks of alcohol in past year

Real annual beer price in 1982-84 dollars ${ }^{b}$

Minimum legal age in years for purchase and consumption of beer, alcoholic content 3.2 percent or less (legal drinking age); multiplied by a dichotomous variable that equals 1 if respondent is 21 years of age or younger $(\text { age } \leq 21)^{b}$

Dichotomous variable that equals 1 if respondent resides in a county within 25 miles of a state with a lower legal drinking age (lower border age indicator); multiplied by a

dichotomous variable that equals 1 if respondent is 21 years of age or younger

Dichotomous variables that identify respondents aged $19,21,23$, and 25 , respectively; omitted category pertains to respondents aged $27^{b}$

Dichotomous indicator

Dichotomous variables that identify Afro-Americans or blacks (Black) and American Indians, Puerto Ricans or other Latin Americans, Mexican Americans or Chicanos, or Orientals or Asian Americans (Other race/ethnicity); omitted category pertains to Caucasians or whites 
Real earnings

$(8417.570,6194.310)$

Years of completed schooling

$(13.504,1.372)$

Full-time college student

$(0.296,0.396)$

Half-time college student

$(0.038,0.165)$

Less than half-time college student $(0.054,0.196)$

Working full-time

$(0.569,0.425)$

Working part-time

$(0.201,0.343)$

Unemployed

$(0.030,0.145)$

Infrequent religious participation $(0.426,0.429)$

Frequent religious participation

$(0.465,0.433)$

Married

$(0.292,0.396)$

Engaged

$(0.084,0.242)$

Separated or divorced

$(0.028,0.144)$

Number of children

$(0.270,0.540)$
Real earnings in the past calendar year in 1982-84 dollars; money earnings divided by the year- and city-specific cost of living index described in the text

Years of formal schooling completed

Dichotomous indicators; omitted category pertains to persons not attending school in March of the survey year

Dichotomous indicators that pertain to first full week of March of the survey year; omitted category identifies respondents not in the labor force

Dichotomous variables that identify respondents who rarely attend religious services (infrequent religious participation) and who attend religious services at least once or twice a month (frequent religious participation), respectively; omitted category pertains to respondents who never attend religious services

Dichotomous indicators; omitted category pertains to single respondents

Respondent's number of children 
1976 high school senior class $(0.155,0.315)$

1977 high school senior class (0.167,0.325)

1978 high school senior class

$(0.141,0.303)$

1979 high school senior class

$(0.135,0.298)$

1980 high school senior class $(0.104,0.266)$

1981 high school senior class $(0.097,0.258)$

1982 high school senior class $(0.069,0.221)$

1983 high school senior class $(0.066,0.216)$

1984 high school senior class $(0.034,0.158)$
Dichotomous variables; omitted category identifies members of the 1985 high school senior class

Means and standard deviations in parentheses. First figure is mean, second figure is standard deviation. Means and standard deviations are weighted by the inverse of the probability of selection; equivalent to multiplying values of a given variable from the illegal drug stratum by one-third. Sample size is 21,420 .

bee text for more details. 
Table 2

Non-addictive Demand Functions, Dependent Variable $=$ Annual Number of Drinks

$$
(n=21,420)
$$

\begin{tabular}{|c|c|c|}
\hline & $(1)$ & $\overline{(2)}$ \\
\hline Price & $\begin{array}{c}-8.158 \\
(-6.48)\end{array}$ & $\begin{array}{c}-4.303 \\
(-3.55)\end{array}$ \\
\hline Legal drinking age*age $\leq 21$ & $\begin{array}{c}-1.106 \\
(-2.55)\end{array}$ & $\begin{array}{c}-1.217 \\
(-2.92)\end{array}$ \\
\hline Lower border drinking age indicator*age $\leq 21$ & $\begin{array}{r}7.789 \\
(5.73) \\
\end{array}$ & $\begin{array}{r}7.323 \\
(5.61) \\
\end{array}$ \\
\hline Age 19 & $\begin{array}{l}39.832 \\
(4.68)\end{array}$ & $\begin{array}{c}30.987 \\
(3.78)\end{array}$ \\
\hline Age 21 & $\begin{array}{l}38.513 \\
(4.47)\end{array}$ & $\begin{array}{l}32.121 \\
(3.88)\end{array}$ \\
\hline Age 23 & $\begin{array}{l}11.985 \\
(6.31)\end{array}$ & $\begin{array}{r}6.357 \\
(3.44)\end{array}$ \\
\hline Age 25 & $\begin{array}{r}7.563 \\
(3.89)\end{array}$ & $\begin{array}{c}4.728 \\
(2.52)\end{array}$ \\
\hline Male & $\begin{array}{c}26.624 \\
(33.42)\end{array}$ & $\begin{array}{c}21.818 \\
(28.09)\end{array}$ \\
\hline Black & $\begin{array}{r}-33.299 \\
(-23.66)\end{array}$ & $\begin{array}{c}-31.869 \\
(-23.14)\end{array}$ \\
\hline Other race/ethnicity & $\begin{array}{c}-13.818 \\
(-9.39)\end{array}$ & $\begin{array}{r}-14.281 \\
(-10.12)\end{array}$ \\
\hline Real earnings & $\begin{array}{l}0.00027 \\
(3.79)\end{array}$ & $\begin{array}{l}0.00043 \\
(6.38)\end{array}$ \\
\hline Years of completed schooling & $\begin{array}{r}1.606 \\
(5.46)\end{array}$ & $\begin{array}{c}0.850 \\
(2.88)\end{array}$ \\
\hline Full-time college student & $\begin{array}{r}8.358 \\
(6.82)\end{array}$ & $\begin{array}{r}3.948 \\
(3.31)\end{array}$ \\
\hline Half-time college student & $\begin{array}{r}1.982 \\
(0.95)\end{array}$ & $\begin{array}{c}-1.316 \\
(-0.66)\end{array}$ \\
\hline Less than half-time college student & $\begin{array}{r}0.785 \\
(0.46)\end{array}$ & $\begin{array}{c}-1.486 \\
(-0.91)\end{array}$ \\
\hline Working full-time & $\begin{array}{r}6.734 \\
(5.52) \\
\end{array}$ & $\begin{array}{r}1.525 \\
(1.27) \\
\end{array}$ \\
\hline Working part-time & $\begin{array}{r}2.103 \\
(1.69)\end{array}$ & $\begin{array}{c}-0.438 \\
(-0.37)\end{array}$ \\
\hline Unemployed & $\begin{array}{r}6.683 \\
(2.81)\end{array}$ & $\begin{array}{r}0.682 \\
(0.30)\end{array}$ \\
\hline Infrequent religious participation & & $\begin{array}{c}-1.544 \\
(-1.31)\end{array}$ \\
\hline Frequent religious participation & & $\begin{array}{r}-23.469 \\
(-19.44)\end{array}$ \\
\hline Married & & $\begin{array}{r}-23.379 \\
(-22.69)\end{array}$ \\
\hline Engaged & & $\begin{array}{c}-9.582 \\
(-7.12)\end{array}$ \\
\hline Separated or divorced & & $\begin{array}{r}6.329 \\
(2.84)\end{array}$ \\
\hline Number of children & & $\begin{array}{c}-3.264 \\
(-4.45)\end{array}$ \\
\hline$\overline{\mathrm{R}}$-squared & 0.104 & 0.176 \\
\hline
\end{tabular}

Note: Asymptotic t-statistics in parentheses, and intercepts not shown. Regrcssors include dichotomous variables for nine of the ten cohorts (the senior classes of 1976 through 1984). 
Table 3

Structural Demand Functions,

Dependent Variable $=$ Annual Number of Drinks

$(n=18,473)$

\begin{tabular}{|c|c|c|c|c|}
\hline & \multicolumn{2}{|c|}{ Two-Stage Least Squares } & \multicolumn{2}{|c|}{ Ordinary Least Squares } \\
\hline & $\overline{(1)}$ & (2) & (3) & (4) \\
\hline Past consumption & $\begin{array}{r}0.254 \\
(4.37)\end{array}$ & $\begin{array}{r}0.274 \\
(8.18)\end{array}$ & $\begin{array}{r}0.346 \\
(60.07)\end{array}$ & $\begin{array}{r}0.338 \\
(58.69)\end{array}$ \\
\hline Future consumption & $\begin{array}{r}0.656 \\
(9.12)\end{array}$ & $\begin{array}{r}0.345 \\
(11.14)\end{array}$ & $\begin{array}{r}0.474 \\
(76.30)\end{array}$ & $\begin{array}{r}0.454 \\
(72.60)\end{array}$ \\
\hline Price & $\begin{array}{l}-2.470 \\
(2.40)\end{array}$ & $\begin{array}{l}-2.155 \\
(2.24)\end{array}$ & $\begin{array}{r}-2.663 \\
(-2.84)\end{array}$ & $\begin{array}{l}-1.744 \\
(-1.87)\end{array}$ \\
\hline Legal drinking age*age $\leq 21$ & $\begin{array}{c}-1.038 \\
(3.12)\end{array}$ & $\begin{array}{l}-1.131 \\
(3.44)\end{array}$ & $\begin{array}{l}-1.015 \\
(-3.14)\end{array}$ & $\begin{array}{r}-1.059 \\
(-3.30)\end{array}$ \\
\hline Lower border drinking age indicator*age $\leq 21$ & $\begin{array}{r}1.597 \\
(1.42)\end{array}$ & $\begin{array}{r}3.379 \\
(3.24) \\
\end{array}$ & $\begin{array}{c}2.139 \\
(2.12)\end{array}$ & $\begin{array}{r}2.203 \\
(2.21)\end{array}$ \\
\hline Age 19 & $\begin{array}{c}23.748 \\
(3.55)\end{array}$ & $\begin{array}{l}26.317 \\
(4.07)\end{array}$ & $\begin{array}{c}26.838 \\
(4.24)\end{array}$ & $\begin{array}{l}23.548 \\
(3.74)\end{array}$ \\
\hline Age 21 & $\begin{array}{c}24.748 \\
(3.70)\end{array}$ & $\begin{array}{l}26.672 \\
(4.08)\end{array}$ & $\begin{array}{l}26.258 \\
(4.09)\end{array}$ & $\begin{array}{l}24.113 \\
(3.78)\end{array}$ \\
\hline Age 23 & $\begin{array}{r}1.738 \\
(1.04)\end{array}$ & $\begin{array}{r}2.490 \\
(1.67)\end{array}$ & $\begin{array}{c}3.256 \\
(2.27)\end{array}$ & $\begin{array}{c}1.362 \\
(0.94)\end{array}$ \\
\hline Age 25 & $\begin{array}{r}2.885 \\
(1.86)\end{array}$ & $\begin{array}{c}3.148 \\
(2.10)\end{array}$ & $\begin{array}{r}3.544 \\
(2.41)\end{array}$ & $\begin{array}{r}2.675 \\
(1.83)\end{array}$ \\
\hline Male & $\begin{array}{r}1.495 \\
(0.80)\end{array}$ & $\begin{array}{r}7.521 \\
(8.03)\end{array}$ & $\begin{array}{r}4.384 \\
(7.13)\end{array}$ & $\begin{array}{r}3.596 \\
(5.86)\end{array}$ \\
\hline Black & $\begin{array}{l}-5.205 \\
(2.25)\end{array}$ & $\begin{array}{r}-13.157 \\
(8.66)\end{array}$ & $\begin{array}{l}-7.178 \\
(-6.29)\end{array}$ & $\begin{array}{c}-8.032 \\
(-6.99)\end{array}$ \\
\hline Other race/ethnicity & $\begin{array}{l}-2.672 \\
(1.90)\end{array}$ & $\begin{array}{l}-6.599 \\
(5.42)\end{array}$ & $\begin{array}{r}-3.965 \\
(-3.48)\end{array}$ & $\begin{array}{r}-4.431 \\
(-3.92)\end{array}$ \\
\hline Real earnings & $\begin{array}{c}0.0001 \\
(1.83)\end{array}$ & $\begin{array}{c}0.00023 \\
(4.09)\end{array}$ & $\begin{array}{c}0.0001 \\
(1.93)\end{array}$ & $\begin{array}{l}0.00017 \\
(3.21)\end{array}$ \\
\hline Years of completed schooling & $\begin{array}{c}0.590 \\
(2.45)\end{array}$ & $\begin{array}{c}0.455 \\
(1.94)\end{array}$ & $\begin{array}{r}0.680 \\
(3.10)\end{array}$ & $\begin{array}{c}0.320 \\
(1.41)\end{array}$ \\
\hline Full-time college student & $\begin{array}{r}1.613 \\
(1.36)\end{array}$ & $\begin{array}{c}2.218 \\
(2.29)\end{array}$ & $\begin{array}{c}3.468 \\
(3.81)\end{array}$ & $\begin{array}{r}1.599 \\
(1.75)\end{array}$ \\
\hline Half-time college student & $\begin{array}{l}-0.164 \\
(0.10)\end{array}$ & $\begin{array}{l}-0.762 \\
(0.48)\end{array}$ & $\begin{array}{r}0.418 \\
(0.27)\end{array}$ & $\begin{array}{c}-0.951 \\
(-0.62)\end{array}$ \\
\hline Less than half-time college student & $\begin{array}{l}-1.582 \\
(1.21)\end{array}$ & $\begin{array}{l}-1.978 \\
(1.54)\end{array}$ & $\begin{array}{c}-1.101 \\
(-0.87)\end{array}$ & $\begin{array}{l}-2.088 \\
(-1.67)\end{array}$ \\
\hline Working full-time & $\begin{array}{r}2.742 \\
(2.74)\end{array}$ & $\begin{array}{r}1.334 \\
(1.41)\end{array}$ & $\begin{array}{c}3.055 \\
(3.36)\end{array}$ & $\begin{array}{r}1.040 \\
(1.13)\end{array}$ \\
\hline Working part-time & $\begin{array}{r}1.390 \\
(1.49\}\end{array}$ & $\begin{array}{r}0.294 \\
(0.32)\end{array}$ & $\begin{array}{r}1.420 \\
(1.56)\end{array}$ & $\begin{array}{r}0.474 \\
(0.52)\end{array}$ \\
\hline Unemployed & $\begin{array}{r}0.701 \\
(0.36)\end{array}$ & $\begin{array}{l}-0.226 \\
(0.12)\end{array}$ & $\begin{array}{c}1.182 \\
(0.65)\end{array}$ & $\begin{array}{c}-0.982 \\
(-0.54)\end{array}$ \\
\hline Infrequent religious participation & & $\begin{array}{l}-0.297 \\
(0.32)\end{array}$ & & $\begin{array}{c}0.0024 \\
(0.003)\end{array}$ \\
\hline Frequent religious participation & & $\begin{array}{l}-9.297 \\
(7.73)\end{array}$ & & $\begin{array}{c}-5.484 \\
(-5.84)\end{array}$ \\
\hline Married & & $\begin{array}{l}-12.719 \\
(12.77)\end{array}$ & & $\begin{array}{r}-9.614 \\
(-11.89)\end{array}$ \\
\hline Engaged & & $\begin{array}{l}-5.666 \\
(5.00)\end{array}$ & & $\begin{array}{r}-4.287 \\
(-4.13)\end{array}$ \\
\hline Separated or divorced & & $\begin{array}{r}6.712 \\
(3.68)\end{array}$ & & $\begin{array}{r}6.900 \\
(3.89)\end{array}$ \\
\hline Number of children & & $\begin{array}{l}-1.932 \\
(3.15)\end{array}$ & & $\begin{array}{l}-1.538 \\
(-2.66)\end{array}$ \\
\hline R-squared & 0.191 & $\frac{0.292}{0.103}$ & 0.568 & 0.576 \\
\hline Wu F-ratio & 3.417 & 16.945 & - & - \\
\hline
\end{tabular}

Note: Asymptotic t-statistics in parentheses, and intercepts not shown. Regressors include dichotomous variables for nine of the ten cohorts (the senior classes of 1976 through 1984). 
Table 4

Price Elasticities of Demand

\begin{tabular}{||l|c|c|c|c||}
\hline \multirow{2}{*}{} & \multicolumn{3}{|c|}{ Two-Stage Least Squares } & \multicolumn{2}{c|}{ Ordinary Least Squares } \\
\cline { 2 - 5 } & $\mathbf{( 1 )}$ & $\mathbf{( 2 )}$ & $\mathbf{( 3 )}$ & $\mathbf{( 4 )}$ \\
\hline Long run & -1.265 & -0.260 & -0.681 & -0.386 \\
\hline Short run & -0.857 & -0.181 & -0.384 & -0.225 \\
\hline Temporary current & -0.144 & -0.111 & -0.154 & -0.099 \\
\hline Temporary past & -0.046 & -0.034 & -0.067 & -0.041 \\
\hline Temporary future & -0.120 & -0.043 & -0.092 & -0.056 \\
\hline
\end{tabular}

Table 5

Price and Consumption Coeffiicents, Two-Stage Least Squares Fixed-Effects Model $(n=17,237)$

\begin{tabular}{|l|c|}
\hline & $\begin{array}{c}\text { Two-Stage } \\
\text { Least Squares }\end{array}$ \\
\hline Past consumption & 0.203 \\
& $(2.01)$ \\
\hline Future consumption & 0.343 \\
& $(1.81)$ \\
\hline Price & -5.337 \\
& $(-2.54)$ \\
\hline R-squared & 0.013 \\
\hline Wu F-ratio & 10.118 \\
\hline Long-run price elasticity & -0.54 \\
\hline
\end{tabular}

Note: Asymptotic t-statistics in parentheses, and intercepts, religious participation, marital status, and number of children not shown. 
Table 6

Structural Demand Functions,

Dependent Variable = Probability of Forty or More Annual Drinking Occasions

$(n=19,145)$

\begin{tabular}{|c|c|c|c|c|}
\hline & \multicolumn{2}{|c|}{ Two-Stage Least Squares } & \multicolumn{2}{|c|}{ Ordinary Least Squares } \\
\hline & (1) & (2) & (3) & (4) \\
\hline Past percentage high & $\begin{array}{l}0.0042 \\
(2.17) \\
\end{array}$ & $\begin{array}{l}0.0042 \\
(4.27)\end{array}$ & $\begin{array}{c}0.0039 \\
(31.52)\end{array}$ & $\begin{array}{l}0.0037 \\
(29.82)\end{array}$ \\
\hline Future percentage high & $\begin{array}{r}0.012 \\
(3.98) \\
\end{array}$ & $\begin{array}{l}0.0048 \\
(4.81) \\
\end{array}$ & $\begin{array}{l}0.0037 \\
(26.15) \\
\end{array}$ & $\begin{array}{l}0.0033 \\
(23.45) \\
\end{array}$ \\
\hline Price & $\begin{array}{l}-0.025 \\
(1.99) \\
\end{array}$ & $\begin{array}{l}-0.023 \\
(2.28) \\
\end{array}$ & $\begin{array}{l}-0.038 \\
(3.72) \\
\end{array}$ & $\begin{array}{l}-0.024 \\
(2.36) \\
\end{array}$ \\
\hline Legal drinking age $*$ age $\leq 21$ & $\begin{array}{l}-0.013 \\
(3.19)\end{array}$ & $\begin{array}{l}-0.014 \\
(3.87) \\
\end{array}$ & $\begin{array}{l}-0.013 \\
(3.72) \\
\end{array}$ & $\begin{array}{l}-0.014 \\
(3.90) \\
\end{array}$ \\
\hline Lower border drinking age indicator*age $\leq 21$ & $\begin{array}{l}-0.00062 \\
(0.043) \\
\end{array}$ & $\begin{array}{r}0.015 \\
(1.31) \\
\end{array}$ & $\begin{array}{r}0.020 \\
(1.82) \\
\end{array}$ & $\begin{array}{r}0.019 \\
(1.78) \\
\end{array}$ \\
\hline Age 19 & $\begin{array}{r}0.209 \\
(2.54) \\
\end{array}$ & $\begin{array}{r}0.219 \\
(3.15) \\
\end{array}$ & $\begin{array}{r}0.290 \\
(4.18)\end{array}$ & $\begin{array}{r}0.232 \\
(3.38) \\
\end{array}$ \\
\hline Age 21 & $\begin{array}{r}0.258 \\
(3.17) \\
\end{array}$ & $\begin{array}{r}0.270 \\
(3.84) \\
\end{array}$ & $\begin{array}{r}0.319 \\
(4.54) \\
\end{array}$ & $\begin{array}{r}0.278 \\
(4.01) \\
\end{array}$ \\
\hline Age 23 & $\begin{array}{l}0.0053 \\
(0.24)\end{array}$ & $\begin{array}{l}0.0093 \\
(0.57) \\
\end{array}$ & $\begin{array}{r}0.049 \\
(3.08)\end{array}$ & $\begin{array}{r}0.016 \\
(1.02) \\
\end{array}$ \\
\hline Age 25 & $\begin{array}{c}0.0091 \\
(0.47) \\
\end{array}$ & $\begin{array}{c}0.013 \\
(0.82) \\
\end{array}$ & $\begin{array}{r}0.032 \\
(1.97) \\
\end{array}$ & $\begin{array}{r}0.016 \\
(1.02) \\
\end{array}$ \\
\hline Male & $\begin{array}{r}0.065 \\
(2.35) \\
\end{array}$ & $\begin{array}{r}0.115 \\
(12.14) \\
\end{array}$ & $\begin{array}{r}0.145 \\
(21.84) \\
\end{array}$ & $\begin{array}{r}0.130 \\
(19.53) \\
\end{array}$ \\
\hline Black & $\begin{array}{l}-0.042 \\
(1.20)\end{array}$ & $\begin{array}{l}-0.115 \\
(7.16) \\
\end{array}$ & $\begin{array}{r}-0.133 \\
(10.88)\end{array}$ & $\begin{array}{r}-0.136 \\
(11.12) \\
\end{array}$ \\
\hline Other race/ethnicity & $\begin{array}{l}-0.014 \\
(0.68) \\
\end{array}$ & $\begin{array}{l}-0.052 \\
(3.95)\end{array}$ & $\begin{array}{l}-0.058 \\
(4.68) \\
\end{array}$ & $\begin{array}{l}-0.062 \\
(5.08) \\
\end{array}$ \\
\hline Real earnings & $\begin{array}{l}0.0000047 \\
(6.72)\end{array}$ & $\begin{array}{l}0.0000047 \\
(8.09)\end{array}$ & $\begin{array}{l}0.0000039 \\
(6.72)\end{array}$ & $\begin{array}{l}0.0000046 \\
(7.98)\end{array}$ \\
\hline Years of completed schooling & $\begin{array}{r}0.030 \\
(8.48)\end{array}$ & $\begin{array}{r}0.017 \\
(6.73)\end{array}$ & $\begin{array}{r}0.023 \\
(9.54)\end{array}$ & $\begin{array}{r}0.016 \\
(6.46)\end{array}$ \\
\hline Full-time college student & $\begin{array}{r}0.031 \\
(2.62) \\
\end{array}$ & $\begin{array}{r}0.013 \\
(1.29) \\
\end{array}$ & $\begin{array}{r}0.040 \\
(4.03) \\
\end{array}$ & $\begin{array}{r}0.013 \\
(1.30) \\
\end{array}$ \\
\hline Half-time college student & $\begin{array}{l}-0.0074 \\
(0.38) \\
\end{array}$ & $\begin{array}{l}-0.018 \\
(1.06)\end{array}$ & $\begin{array}{l}0.0029 \\
(0.17) \\
\end{array}$ & $\begin{array}{l}-0.017 \\
(1.01)\end{array}$ \\
\hline Less than half-time college student & $\begin{array}{c}0.016 \\
(1.01) \\
\end{array}$ & $\begin{array}{l}0.0022 \\
(0.16) \\
\end{array}$ & $\begin{array}{r}0.014 \\
(1.03) \\
\end{array}$ & $\begin{array}{r}0.0011 \\
(0.077) \\
\end{array}$ \\
\hline Working full-time & $\begin{array}{r}0.044 \\
(3.66) \\
\end{array}$ & $\begin{array}{r}0.015 \\
(1.46)\end{array}$ & $\begin{array}{r}0.045 \\
(4.53) \\
\end{array}$ & $\begin{array}{r}0.015 \\
(1.46) \\
\end{array}$ \\
\hline Working part-time & $\begin{array}{r}0.025 \\
(2.17)\end{array}$ & $\begin{array}{l}0.0053 \\
(0.53)\end{array}$ & $\begin{array}{r}0.018 \\
(1.78)\end{array}$ & $\begin{array}{l}0.0033 \\
(0.34)\end{array}$ \\
\hline Unemployed & $\begin{array}{l}0.00049 \\
(0.02)\end{array}$ & $\begin{array}{l}-0.009 \\
(0.45) \\
\end{array}$ & $\begin{array}{r}0.027 \\
(1.35) \\
\end{array}$ & $\begin{array}{l}-0.0039 \\
(0.20) \\
\end{array}$ \\
\hline Infrequent religious participation & & $\begin{array}{l}-0.0047 \\
(0.47)\end{array}$ & & $\begin{array}{l}-0.0072 \\
(0.73)\end{array}$ \\
\hline Frequent religious participation & & $\begin{array}{l}-0.060 \\
(4.22) \\
\end{array}$ & & $\begin{array}{l}-0.080 \\
(7.74) \\
\end{array}$ \\
\hline Married & & $\begin{array}{r}-0.111 \\
(10.95) \\
\end{array}$ & & $\begin{array}{r}-0.122 \\
(13.90) \\
\end{array}$ \\
\hline Engaged & & $\begin{array}{l}-0.037 \\
(3.06) \\
\end{array}$ & & $\begin{array}{l}-0.043 \\
(3.83) \\
\end{array}$ \\
\hline Separated or divorced & & $\begin{array}{r}0.042 \\
(2.14) \\
\end{array}$ & & $\begin{array}{r}0.043 \\
(2.22) \\
\end{array}$ \\
\hline Number of children & & $\begin{array}{l}-0.030 \\
(4.76)\end{array}$ & & $\begin{array}{l}-0.029 \\
(4.65)\end{array}$ \\
\hline R-squared & 0.086 & 0.153 & 0.215 & 0.236 \\
\hline Wu F-ratio & 5.887 & 2.685 & - & - \\
\hline
\end{tabular}

Note: Asymptotic t-statistics in parentheses, and intercepts not shown. Regressors include dichotomous variables for nine of the ten cohorts (the senior classes of 1976 through 1984). 
Table 7

Structural Demand runctions,

Dependent Variat: $=$ Probability of Forty or More Annual Dribling Occasions,

Past and Future Probabilities I $\mathrm{r}$ luded

$(\mathrm{n}=18,579)$

\begin{tabular}{|c|c|c|c|c|}
\hline & \multicolumn{2}{|c|}{ Two-Stage Least Squares } & \multicolumn{2}{|c|}{ Ordinary Least Squares } \\
\hline & (1) & (2) & (3) & (4) \\
\hline Past probability & $\begin{array}{r}0.199 \\
(2.21)\end{array}$ & $\begin{array}{r}0.252 \\
(5.18)\end{array}$ & $\begin{array}{r}0.326 \\
(49.93) \\
\end{array}$ & $\begin{array}{r}0.317 \\
(48.45)\end{array}$ \\
\hline Future probability & $\begin{array}{r}0.651 \\
(6.59) \\
\end{array}$ & $\begin{array}{c}0.348 \\
(8.34)\end{array}$ & $\begin{array}{r}0.402 \\
(62.57)\end{array}$ & $\begin{array}{r}0.387 \\
(59.93)\end{array}$ \\
\hline Price & $\begin{array}{l}-0.021 \\
(2.06) \\
\end{array}$ & $\begin{array}{l}-0.013 \\
(1.46) \\
\end{array}$ & $\begin{array}{l}-0.020 \\
(2.24) \\
\end{array}$ & $\begin{array}{l}-0.011 \\
(1.26)\end{array}$ \\
\hline Legal drinking age*age $\leq 21$ & $\begin{array}{l}-0.010 \\
(3.13)\end{array}$ & $\begin{array}{l}-0.011 \\
(3.56) \\
\end{array}$ & $\begin{array}{l}-0.010 \\
(3.19) \\
\end{array}$ & $\begin{array}{l}-0.010 \\
(3.38)\end{array}$ \\
\hline Lower border drinking age indicator*age $\leq 21$ & $\begin{array}{l}0.0044 \\
(0.42)\end{array}$ & $\begin{array}{r}0.014 \\
(1.43)\end{array}$ & $\begin{array}{r}0.010 \\
(1.06)\end{array}$ & $\begin{array}{r}0.010 \\
(1.06)\end{array}$ \\
\hline Age 19 & $\begin{array}{r}0.224 \\
(3.47)\end{array}$ & $\begin{array}{r}0.236 \\
(3.87) \\
\end{array}$ & $\begin{array}{r}0.252 \\
(4.17) \\
\end{array}$ & $\begin{array}{r}0.226 \\
(3.74)\end{array}$ \\
\hline Age 21 & $\begin{array}{r}0.240 \\
(3.66)\end{array}$ & $\begin{array}{r}0.247 \\
(4.01)\end{array}$ & $\begin{array}{r}0.250 \\
(4.07)\end{array}$ & $\begin{array}{r}0.233 \\
(3.82)\end{array}$ \\
\hline Age 23 & $\begin{array}{r}0.020 \\
(1.30) \\
\end{array}$ & $\begin{array}{r}0.016 \\
(1.18)\end{array}$ & $\begin{array}{r}0.031 \\
(2.24)\end{array}$ & $\begin{array}{r}0.014 \\
(0.99) \\
\end{array}$ \\
\hline Age 25 & $\begin{array}{r}0.019 \\
(1.29) \\
\end{array}$ & $\begin{array}{r}0.015 \\
(1.09) \\
\end{array}$ & $\begin{array}{r}0.021 \\
(1.52)\end{array}$ & $\begin{array}{r}0.013 \\
(0.96)\end{array}$ \\
\hline Male & $\begin{array}{r}0.023 \\
(1.18)\end{array}$ & $\begin{array}{r}0.069 \\
(7.00)\end{array}$ & $\begin{array}{r}0.059 \\
(10.08)\end{array}$ & $\begin{array}{r}0.051 \\
(8.65)\end{array}$ \\
\hline Black & $\begin{array}{l}-0.048 \\
(2.35)\end{array}$ & $\begin{array}{l}-0.095 \\
(6.82)\end{array}$ & $\begin{array}{l}-0.070 \\
(6.48)\end{array}$ & $\begin{array}{l}-0.075 \\
(6.82)\end{array}$ \\
\hline Other race/ethnicity & $\begin{array}{l}-0.027 \\
(2.03) \\
\end{array}$ & $\begin{array}{l}-0.051 \\
(4.50) \\
\end{array}$ & $\begin{array}{l}-0.041 \\
(3.73) \\
\end{array}$ & $\begin{array}{l}-0.044 \\
(4.05) \\
\end{array}$ \\
\hline Real earnings & $\begin{array}{l}0.0000013 \\
(2.19)\end{array}$ & $\begin{array}{l}0.0000021 \\
(3.96)\end{array}$ & $\begin{array}{l}0.0000012 \\
(2.34)\end{array}$ & $\begin{array}{l}0.0000018 \\
(3.48)\end{array}$ \\
\hline Years of completed schooling & $\begin{array}{c}0.0057 \\
(2.24) \\
\end{array}$ & $\begin{array}{l}0.0065 \\
(2.91)\end{array}$ & $\begin{array}{c}0.0085 \\
(4.06) \\
\end{array}$ & $\begin{array}{c}0.0058 \\
(2.65) \\
\end{array}$ \\
\hline Full-time college student & $\begin{array}{l}-0.0069 \\
(0.62)\end{array}$ & $\begin{array}{l}-0.0049 \\
(0.54)\end{array}$ & $\begin{array}{l}0.0093 \\
(1.07) \\
\end{array}$ & $\begin{array}{l}-0.0058 \\
(0.67) \\
\end{array}$ \\
\hline Half-time college student & $\begin{array}{l}-0.0087 \\
(0.56)\end{array}$ & $\begin{array}{l}-0.014 \\
(0.94)\end{array}$ & $\begin{array}{l}-0.003 \\
(0.20) \\
\end{array}$ & $\begin{array}{l}-0.014 \\
(0.97)\end{array}$ \\
\hline Less than half-time college student & $\begin{array}{l}-0.0037 \\
(0.29)\end{array}$ & $\begin{array}{l}-0.005 \\
(0.42)\end{array}$ & $\begin{array}{l}0.0023 \\
(0.19) \\
\end{array}$ & $\begin{array}{l}-0.0055 \\
(0.46)\end{array}$ \\
\hline Working full-time & $\begin{array}{c}0.018 \\
(1.82)\end{array}$ & $\begin{array}{r}0.009 \\
(1.01)\end{array}$ & $\begin{array}{c}0.024 \\
(2.77) \\
\end{array}$ & $\begin{array}{c}0.0079 \\
(0.89) \\
\end{array}$ \\
\hline Working part-time & $\begin{array}{c}0.0019 \\
(0.20) \\
\end{array}$ & $\begin{array}{l}-0.0022 \\
(0.25) \\
\end{array}$ & $\begin{array}{r}0.005 \\
(0.58) \\
\end{array}$ & $\begin{array}{l}-0.0023 \\
(0.26) \\
\end{array}$ \\
\hline Unemployed & $\begin{array}{r}0.023 \\
(1.21)\end{array}$ & $\begin{array}{r}0.015 \\
(0.85)\end{array}$ & $\begin{array}{r}0.031 \\
(1.76) \\
\end{array}$ & $\begin{array}{r}0.013 \\
(0.72)\end{array}$ \\
\hline Infrequent religious participation & & $\begin{array}{l}-0.010 \\
(1.10)\end{array}$ & & $\begin{array}{l}-0.0079 \\
(0.91)\end{array}$ \\
\hline Frequent religious participation & & $\begin{array}{l}-0.072 \\
(6.55) \\
\end{array}$ & & $\begin{array}{l}-0.057 \\
(6.39)\end{array}$ \\
\hline Married & & $\begin{array}{l}-0.090 \\
(9.52)\end{array}$ & & $\begin{array}{r}-0.079 \\
(10.23)\end{array}$ \\
\hline Engaged & & $\begin{array}{l}-0.034 \\
(3.11)\end{array}$ & & $\begin{array}{l}-0.032 \\
(3.18)\end{array}$ \\
\hline Separated or divorced & & $\begin{array}{r}0.041 \\
(2.37)\end{array}$ & & $\begin{array}{l}0.042 \\
(2.49)\end{array}$ \\
\hline Number of children & & $\begin{array}{l}-0.014 \\
(2.37)\end{array}$ & & $\begin{array}{l}-0.011 \\
(1.97)\end{array}$ \\
\hline R-squared & 0.128 & 0.197 & 0.425 & 0.433 \\
\hline Wu F-ratio & 3.468 & 2.809 & - & - \\
\hline
\end{tabular}

Note: Asymptotic t-statistics in parentheses, and intercepts not shown. Regressors include dichotomous variables for nine of the ten cohorts (the senior classes of 1976 through 1984). 